International Journal of

Supply Chain

Management

(IJSCM)

INFLUENCE OF TOP MANAGEMENT SUPPORT ON PROCUREMENT REGULATORY COMPLIANCE LEVEL/IN P.UPTIC UNIVERSITIES IN KENYA

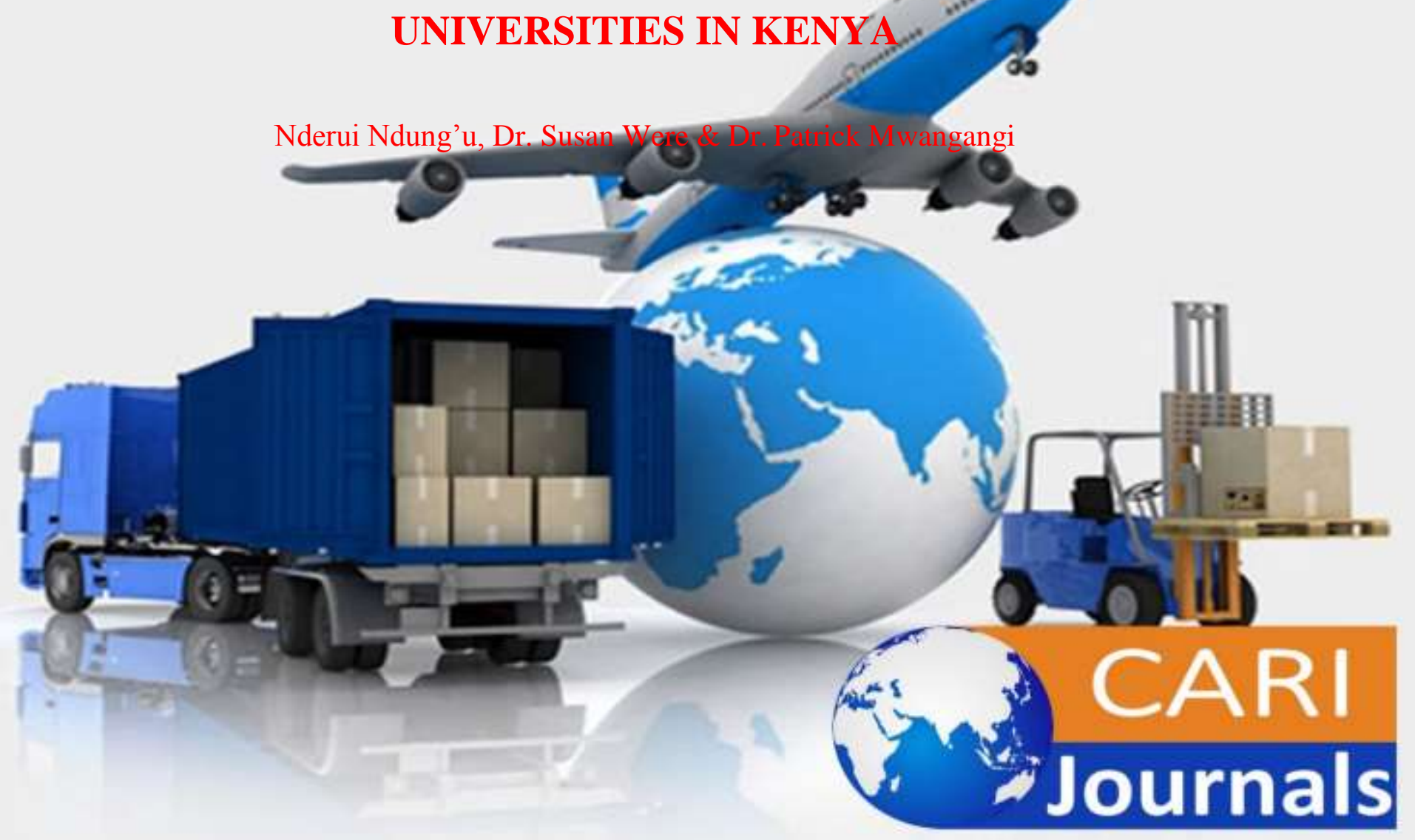




\title{
INFLUENCE OF TOP MANAGEMENT SUPPORT ON PROCUREMENT REGULATORY COMPLIANCE LEVEL IN PUBLIC UNIVERSITIES IN KENYA
}

\author{
1*Nderui Ndung'u \\ Post-Graduate: Jomo Kenyatta University of Agriculture and Technology \\ $2^{*}$ Dr. Susan Were \\ Lecturer: Jomo Kenyatta University of Agriculture and Technology \\ ${ }^{3 *}$ Dr. Patrick Mwangangi \\ Lecturer: Jomo Kenyatta University of Agriculture and Technology \\ Corresponding Author's Email: nderui84@gmail.com
}

\begin{abstract}
Purpose: This research focused on the influence of top management support on procurement regulatory compliance level in public universities in Kenya.

Methodology: The study used Ex-post facto design, the research design was chosen because the study aimed at investigating the causal relationship on variables, which cannot be controlled by the researcher. The researcher applied the census sampling technique to select the sample size of 31 public universities and 333 respondents. The study was informed by the Principal-Agent Theory. Primary data was collected through the use of questionnaires issued to the procurement staffs in the sampled universities. This study undertook a census because the sample size was small. Data collected from the field was coded and cleaned to remove outliers or missing values and categorized manually according to the questionnaire items using frequency distribution tables and percentages. The researcher used both descriptive and inferential statistics with the help of statistical package of Social Science (SPSS) version 24 to analyze the data.
\end{abstract}

Findings: Top management was found to be satisfactory significant in contribution as a factor to procurement regulatory compliance level. The $\mathrm{p}$ value 0.000 was less than the conventional probability of 0.05 at a testing at $95 \%$ level of significance. Motivation and rewards to staff can be used as a strategy to combat the personal interest that arise in preference to fulfill their duties and assignments. Management acts as the framework to the functionality of the procurement department and activities thereof. Top management making efforts on motivating the staff individually leads to an exemplary performance.

Unique contribution to theory, policy and practice: Deficient checking and assessment of the functioning in an organization is connected to the non-attendance to a controllable situation. The existing hindrances from the top management for the staffs to engage and enhance adoption and application of total quality management in procurement should be eradicated. Disciplinary steps should be taken on staff with unbecoming behaviors in effort to uphold ethical practice. There should be freedom of staff to discharge their duties as assigned to them by the top management

Key words: top management support, procurement compliance level, procurement regulatory, public universities in Kenya. 
International Journal of Supply Chain and Logistics

ISSN 2520-3983 (Online)

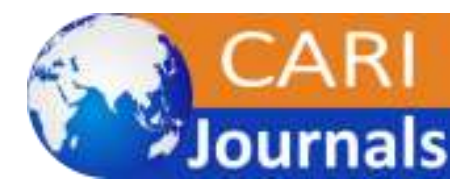

Vol.4, Issue 1, No.1, pp 1 - 12, 2020

www.carijournals.org

\section{INTRODUCTION}

\section{Background of the study}

Kipchilat (2017) citing a COMESA report (2016) noticed that acquisition spend more than 60 percent of government utilize and this calls for obligation in all dimensions as a basic stride. These figure $60 \%$ exhibits that open procurement is fundamental in the economies of both make and slightest created nations. Open obtainment has turned into a noteworthy issue of open concern and consideration in both created and creating nations, and endeavors have been coordinated to its changes, rebuilding, guidelines and regulations,(Public Procurement and Regulatory Authority,2017). Expanding levels of procurements centralization is a requisite for this reform particularly with the introduction of Efficiency and Reform Group within the cabinet secretaries' office in 2010 (Perry, 2017). The real deterrent in any case, has been deficient administrative compliance level (De Boer 2017), procurement administrative rebelliousness issue influences the underdeveloped nations as well as nations in the European Union, (Onyinkwa,2015).

Compliance level audits and checks are seen as value addition not necessary for profiling and exposing executed activities but basically and ideally by being proactive, identifying lessons learnt and disseminating best practice,(Mapesa, 2017).Further the compliance level checks and audits have a direct and positive influence on the way institutions and staffs in the public service execute their duties and responsibilities to the people who are ultimately the customers and beneficially of a given system,(Mapesa, 2017).

The desire and need for University education and training has kept on expanding with numerous understudies of those who can't invest in Kenyan Universities looking for admission in universities abroad, (Commission of University Education, 2018). The number of students enrollment in the university in the last 14 years has substantially increased, the enrollment grew from 30,000 in 2005 to over 100,000 students in 2018, (Basic education Act, 2019).

The objective of the Ministry of Education Act (2015), is provision, promotion, and coordination of long term education, training, research and development, for sustainable development.From,2003 the government of Kenya, introduced various reforms in education sector including establishment of free primary education, for all Kenyan children. In 2006 saw the Government of Kenya, through the Ministry Of Education steadily increase its support to the public universities and further fund expenditure for the development to ensure sustainability. Consequently, since 2005 the Government of Kenya has been elevating numerous technical colleges to university status to accommodate the growing enrollment (Ministry Of Education, 2017).

\section{Statement of the problem}

Akech (2015) noted that public procurement assumes a key job in the age of nation riches as it represents around $60 \%$ of most nations GDPs growth. Malawi spends over $40 \%$ of its financial plan on acquirement while it is assessed that between U\$30-43 billion in the acquisition showcase is probably going to be abused in Sub-Saharan Africa because of procurement inappropriateness (Agaba \& Shipman, 2017). With the end goal to enhance administration of open acquirement tasks, numerous nations concocted changes activities in the most recent years of the twentieth century. 
Getuno et al., (2015) these changes were started by the World Banks to advance productivity, economy, responsibility and straightforwardness in the general population acquirement framework. In Uganda, an expected USh. 300 billion, comparable to Ksh. 10 billion are lost yearly as indicated by African Peer Review Mechanism report (2017). Kenya Institute of Supply chain Management, (2018) affirms that the general population part free over Kshs.8billion yearly because of low compliance levels with acquisition requirements. In any case, as indicated by the Ethics and Anti-Corruption Commission (2018) report, government lost over Ksh. 23 billion through spurned acquisition tasks with the Ministry of Education accounting for $45 \%$ of the detailed cases.

Public Procurement and Oversight Authority report, (2017) note that acquired goods and sevices in the public sector was underneath $30 \%$ compliance level with the Ministry of Education representing $10 \%$ underneath the Ministries of Youth and Gender at $15 \%$ and Ministry of Transport at 20\%. Njeru et al., (2016) opines that low compliance levels in overall speaking acquisition rehearses in most state funded colleges in Kenya contributes to a loss of over Kshs.80 Million yearly and this has remained to a great extent unaltered since 2006. Victor (2015), propose that organization acquisition expenses could be lessened through watching a higher procurement compliance level.

Studies led on procurement compliance level in the public sector incorporate, Gelderman et al., (2017). However, none clarifies why the reforms started way back in the most recent decade of the twentieth century have neglected to pay and emerge, (Migosi, Ombuki \& Evusa,2015). By and by, Odhiambo \& Kamau (2015) recommend that negative effects on reforms might be clarified, to some degree, by poor top management support. This study henceforth was embraced to plug this hole.

\section{Objective of the study}

To establish the influence of top management support on procurement regulatory compliance level in public universities in Kenya

\section{LITERATURE REVIEW}

\section{Theoretical Review}

\section{Principal-Agent Theory}

Alchian and Barry Demsetz (1972) put forward the agency theory also called principal-agent theory. The scholars posits that the principal delegates works to his agent, (procurement manager) through mutual cooperation to act on his behalf. In this case, two potential goals conflict are likely to happen, that of agency problem and risk sharing problem, as each party pulls to its self-interests, (Xingxing \& Kaynak,2017). In the context of the study, Supply chain officers what is more, acquirement supervisors in broad daylight division assume the specialist job for the legislature and the association partners (Transparency International, 2017).The foremost operator hypothesis is an organization show developed by economists that arrangements with circumstances in which the main is in position to impact the specialist, to do a few exercises to the foremost advantage, however not really the operator, (Health \& Norman, 2017 ). 
Donahue (2018) clarifies that acquisition supervisors including all production network officers, worried about open obtainment which assume the operator job for their bosses. Acquirement administrative rebelliousness may show a primary specialist issue. The Public Procurement and Disposal Act (2005) gives the duty of consistence with acquirement procurement law system on the bookkeeping officers of the Public Entity (Getuno, Ngugi, Awino \& Ondieki, 2015). Davis et al.,(2016) asserts that principal/agent relationship is one among the conceivable dangers whereby acquisition directors express their lack of concern towards essentials favored results or not withstanding superseding of the key's preferences that then results into non-compliance.

The postulators of organization hypothesis ground their contentions absolutely on the financial matters features of the model in investigating the relationship between firm administrators and firm proprietors (Davis \& Canes, 2017). This hypothesis assisted us with investigating the impact of best administration bolster openly the procurement compliance level as acquisition administrators are viewed as operators for the association thus the hypothesis support the study topic top management support in that it is built in the assumption that in acquirement work, the issue is one of choosing a legal framework that will deliver conduct by the operator predictable with the Manager inclinations, (Arrowsmith, 2015).

\section{Empirical Review}

Etse and Asenso-Boakye (2017) carried out a study on the components affecting compliance level with people in general procurement law in Ghana. The study revaled that powerless best administration bolster in acquisition framework has a measurably critical effect on consistence level. It also discovered that poor record administration rehearses influence obtainment proficiency in associations as it were. The investigation prescribes that the company's satisfactory controls ought to be set up by presentation of benefiting solid best administration bolster and having set up an information administration programming for overseeing records in contact with these both inward and outside partners ought to be associated with the electronic information programming for Transparency and effectiveness.

The manager role in creating and directing entrepreneurial behavior is crucial. Basically, managers can provide facilities and mobilize organizational resource to achieve high level of organizational performance, (Were et al, 2017). Managers can represent different styles which involve a fast adaption and acceptance of employees valuable opinions, championing ideas, peoples acknowledgement to do and complete forward ideas, providing necessary resources, or introducing entrepreneurship in different aspects like manners, procedures and processes in the firm (Antoncic \& Hisrich, 2016).

Hui et al.,(2017) stipulates that proper allocation of duties and responsibilities is the strategy for promoting accountability and transparency and provides grounds for the level of compliance to rules and regulations pertaining a particular organization and industry at large. Rossi (2017) asserts that formal obligations should initially be characterized obviously, settled upon, and connected best down inside and inside an association in the event that they are to be successful and proficient. Open substance with open pledge to public obtainment compliance level is uncovered by best administration responsibility to principled corporate execution, (Tom, 2017). Compliance culture 
in an association must begin in the meeting room and ought to be reflected, vested and confirm in executives possess practices and mentalities

In a study by Obanda (2016), the author addressed that resilient institutional support by top levels management is required by procurement employees to stimulate honesty, integrity, monitor the public procurement process and apply procurement regulations correctly. To ensure that effective compliance with procurement regulatory principles are practiced and procurement noncompliance are avoided, regular supervision and administration must be safeguarded, (Odhiambo \& Kamau, 2016).

\section{METHODOLOGY}

This study adopted the ex-post facto survey research design. The Ex-post facto design enabled the researcher to examine cause-and-effect relationship(s) where it was impossible, or unethical to manipulate the independent variable. The casual comparative method or ex post facto method of research seek to establish casual relationships between events and circumstances. The target population was a total of thirty one chartered public universities in Kenya which acted as the unit of analysis. Public universities were selected since they have a well structure of administration, coupled with an adequate financial resource from the taxpayers. The number of procurement staffs was obtained from the payroll department through the Integrated Personnel Payroll Data. A sample was drawn from this sampling frame which comprised of 31 public universities. The study sample comprised of 333 respondents with respect to the unit of observation which included, 31chief procurement officers, 31 Principal procurement officers, 31Senior procurement officers and 240 procurement officers in 31 Kenya public universities. The study only considered procurement staffs since they are the ones accountable for speeding up key procurement decisions and thus plentifully supplied with wanted specialized information and aptitudes on the antecedents of procurement regulatory compliance level in public universities in Kenya.

This study undertook a census because the population size was small. This study further utilized questionnaires to collect primary data as used in various previous research projects. Questionnaires containing closed and open ended questions was issued to procurement staffs in the university. The study piloted the tools with Jomo Kenyatta University of Agriculture and Technology. The validity of the questionnaires was determined using Construct validity method using a panel of experts familiar with the construct. Data collected from the field was coded and cleaned to remove outliers or missing values and categorized manually according to the questionnaire items using frequency distribution tables and percentages. The researcher used both descriptive and inferential statistics with the help of statistical package of Social Science (SPSS) version 24 to analyze the data.

\section{RESULTS AND FINDINGS}

\section{Response Rate}

The study distributed a total of 333 questionnaires which was the sample size of the study. A total of 309 questionnaires were completed and returned from the 333 questionnaires sent to the respondents representing $93 \%$ of the response rate. 
International Journal of Supply Chain and Logistics

ISSN 2520-3983 (Online)

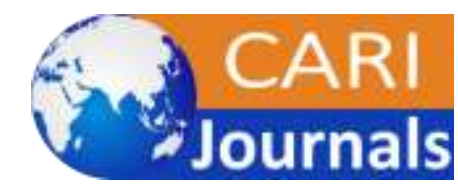

Vol.4, Issue 1, No.1, pp 1 - 12, 2020

www.carijournals.org

\section{Registration with Professional Body}

The study assessed the status of registration of the procurement body in the public universities with any existing professional body in the nation. Majority $(84 \%)$ of the procurement departments in the public universities have not been registered with any professional body specialized in procuring activities.

Table 1 Registration with Professional Body

\begin{tabular}{lcc}
\hline & Frequency & Percent \\
\hline Yes & 45 & 15.8 \\
No & 264 & 84.2 \\
Total & $\mathbf{3 0 9}$ & $\mathbf{1 0 0}$ \\
\hline
\end{tabular}

\section{Top management support and procurement regulatory compliance level}

As per the illustrations in Table 2, majority of the respondents agreed with the statement that top management ignores the importance of implementation of TQM. 5\% agreed with the statement and further $94 \%$ strongly agreed with the statement. Very few respondents (1\%) disagreed with the statement. Majority of the survey participants were in agreement with the statement that top management hinders procurement staffs to adopt TQM. 6\% were in agreed and further 93\% strongly agreed to the statement. A total of less than $1 \%$ of the respondents were undecided whereas others were disagreeing with the statement. The mean of the responses was high at 4.91. In a similar linked study Obanda (2016) addressed that resilient institutional support by top levels management is required by procurement employees to stimulate honesty, integrity, monitor the public procurement process and apply procurement regulations correctly.

The opinion of different respondents on the statement that top management fails to motivate and reward staffs for their effective performance in quality provision. The results revealed that $89 \%$ of the respondents agreed with the statement. $3 \%$ of the respondents had a neutral opinion over the issue. Few respondents $(8 \%)$ totally disagreed with the statement. The mean of the responses and the standard deviation was 4.59 and 1.01 respectively. As referred to by Geo (2017) compliance culture involves association which must begin in the meeting room and ought to be reflected, vested and confirm in executives possess practices and mentalities as directed and monitored by the top management.

Most of the respondents agreed with the statement that there is a poor working environment between the procurement staffs and the top management where $98 \%$ strongly agreed to the statement. Other few respondents were undecided in their opinion (1\%) and few disagreed with the statement $(1 \%)$. The mean of the responses was high at 4.89 . The standard deviation was low at 0.49 .

Majority of the respondents (99\%) were in agreement with the statement that top management denies employees the required authority to do their work. The rest of the respondents (1\%) disagreed with the statement. The mean of the responses and the standard deviation was with the 
International Journal of Supply Chain and Logistics

ISSN 2520-3983 (Online)

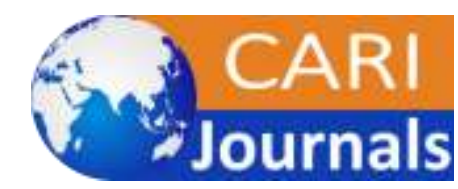

Vol.4, Issue 1, No.1, pp 1 - 12, 2020

www.carijournals.org

values 4.92 and 0.39 respectively. This indicated that the mean was high and a low standard deviation.

Most of the respondents were in agreement with the statement that top management provides employees with the required resources to do their assigned duties. 99\% of the respondents recorded an agreement, $1 \%$ recorded a disagreement with the statement. The mean of the responses was 4.92 and the standard deviation was 0.39 .

Table 2 Top management support

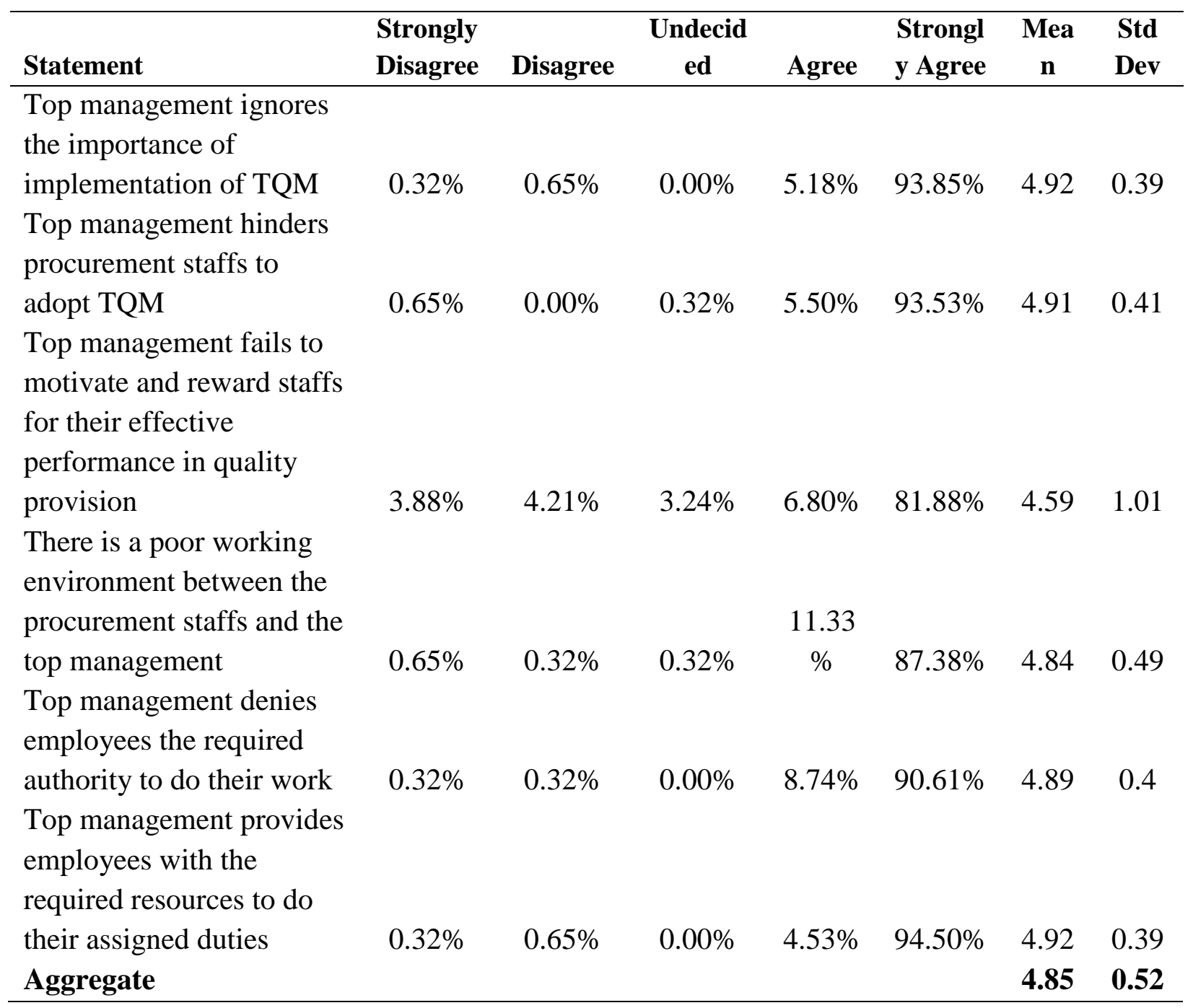


International Journal of Supply Chain and Logistics

ISSN 2520-3983 (Online)

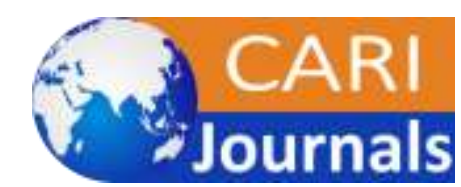

Vol.4, Issue 1, No.1, pp 1 - 12, 2020

www.carijournals.org

\section{Correlation Analysis}

Table 3 Correlation test of top management support

\begin{tabular}{llcc}
\hline & \multicolumn{1}{c}{$\begin{array}{c}\text { top management } \\
\text { support }\end{array}$} & $\begin{array}{c}\text { procurement regulatory } \\
\text { compliance level }\end{array}$ \\
\hline top management support & $\begin{array}{l}\text { Pearson } \\
\text { Correlation }\end{array}$ & 1 & \\
procurement regulatory & \multicolumn{1}{c}{ Sig. (2-tailed) } & \\
compliance level & $\begin{array}{l}\text { Pearson } \\
\text { Correlation } \\
\text { Sig. }(2- \\
\text { tailed) }\end{array}$ & $.698^{* *}$ & 1 \\
\hline
\end{tabular}

** Correlation is significant at the 0.01 level (2-tailed).

The results in Table 3 revealed that there was a positive and significant association between top management support and procurement regulatory compliance level $(r=0.698, p=0.000)$. This implied that procurement expertise factors have contributed to the resulted to the level of compliance to the procurement regulatory. This correlation coefficient value was between 0.6 and 0.7 indicating a strong positive correlation as a factor of procurement regulatory compliance level. A 2-tailed test at $95 \%$ level of confidence had a probability value of less than 0.05 which implied that there was a significant correlation between top management support and procurement regulatory compliance level in public universities.

\section{Regression Analysis}

Regression analysis was done to determine the influence of top management support on procurement regulatory compliance level. Results were presented in Table 4

Table 4 Model summary

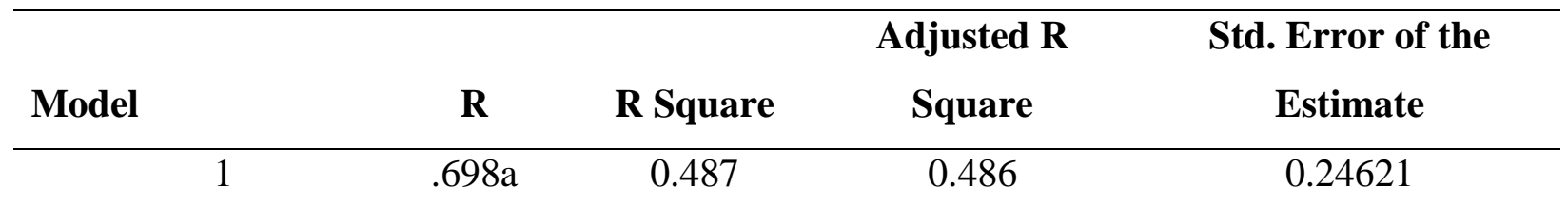

a Predictors: (Constant), top management

support

b Dependent Variable: procurement regulatory

compliance level

The results in Table 4 presented the fitness of model of regression model used in explaining the study phenomena. Top management support was found to be satisfactory in explaining procurement regulatory compliance level. This was supported by coefficient of determination i.e. the R square of $48.7 \%$. This shows that top management support explain $48.7 \%$ of procurement regulatory compliance level. The results meant that the model applied to link the relationship. This 
International Journal of Supply Chain and Logistics

ISSN 2520-3983 (Online)

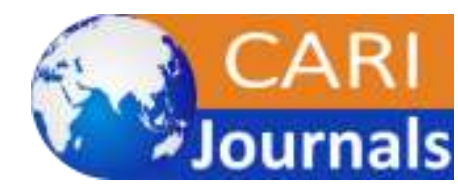

Vol.4, Issue 1, No.1, pp 1 - 12, 2020

www.carijournals.org

further implied that $51.3 \%$ of the variation in the dependent variable is attributed to other variables not captured in the model.

Table 5 ANOVA for top management support

\begin{tabular}{lllccccc}
\hline Model & & Sum of Squares & df & Mean Square & F & Sig. \\
\hline & 1 & Regression & 17.7 & 1 & 17.7 & 291.979 & $.000 \mathrm{~b}$ \\
& Residual & 18.61 & 307 & 0.061 & & \\
& Total & $\mathbf{3 6 . 3 1}$ & $\mathbf{3 0 8}$ & & & \\
& & & & & & \\
\hline
\end{tabular}

a Dependent Variable: procurement regulatory

compliance level

b Predictors: (Constant), top management support

Table 5 provided the results on the analysis of the variance (ANOVA). The results indicated that the model was statistically significant. This was supported by an F statistic of 291.979 and the reported $\mathrm{p}$ value $(0.000)$ which was less than the conventional probability of 0.05 significance level. The results implied that top management support is a good predictor of procurement regulatory compliance level. The findings agree with that of a research by Etse, \& Asenso-Boakye, (2017) carried out on the components affecting compliance level with people in general procurement law in Ghana set up that powerless best administration bolster in acquisition framework has a measurably critical effect on consistence level.

Table 6 Regression of Coefficients for top management support

\begin{tabular}{|c|c|c|c|c|c|c|}
\hline \multirow[t]{2}{*}{ Model } & & \multicolumn{2}{|c|}{$\begin{array}{c}\text { Unstandardized } \\
\text { Coefficients } \\
\text { Std. }\end{array}$} & \multirow{2}{*}{$\begin{array}{c}\text { Standardized } \\
\text { Coefficients } \\
\text { Beta }\end{array}$} & \multirow[t]{2}{*}{$\mathbf{t}$} & \multirow[t]{2}{*}{ Sig. } \\
\hline & & B & Error & & & \\
\hline \multirow[t]{3}{*}{1} & (Constant) & 1.494 & 0.199 & & 7.513 & 0.000 \\
\hline & top management & & & & & \\
\hline & support & 0.699 & 0.041 & 0.698 & 17.087 & 0.000 \\
\hline
\end{tabular}

a Dependent Variable: top management support

Regression of coefficients results in Table 6 revealed that top management support and procurement regulatory compliance level are positively and significantly related $(\beta=0.699$, $\mathrm{p}=0.000$ ). This implies that a unit increase in the factor of top management support would lead to increase in procurement regulatory compliance level by 0.699 . Similar findings are as a study by Were (2017) who argues that the manager role in creating and directing entrepreneurial behavior is crucial. Basically, managers can provide facilities and mobilize organizational resource to achieve high level of organizational performance. 
International Journal of Supply Chain and Logistics

ISSN 2520-3983 (Online)

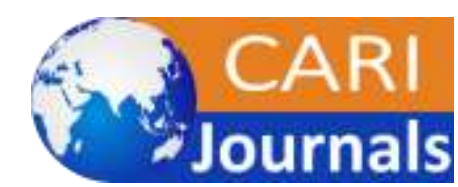

Vol.4, Issue 1, No.1, pp 1 - 12, 2020

www.carijournals.org

\section{SUMMARY, CONCLUSION AND RECOMMENDATIONS}

\section{Summary}

The objective of the study was to establish the influence of top management support on procurement regulatory compliance level in public universities in Kenya. The correlation analysis results revealed that there was a positive and significant association between top management support and procurement regulatory compliance level $(r=0.698, p=0.000)$. This implied that procurement expertise factors have contributed to the resulted to the level of compliance to the procurement regulatory. This correlation coefficient value was between 0.6 and 0.7 indicating a strong positive correlation as a factor of procurement regulatory compliance level. A 2-tailed test at $95 \%$ level of confidence had a probability value of less than 0.05 which implied that there was a significant correlation between top management support and procurement regulatory compliance level in public universities. Regression of coefficients results revealed that top management support and procurement regulatory compliance level are positively and significantly related $(\beta$ $=0.699, \mathrm{p}=0.000$ ). This implies that a unit increase in the factor of top management support would lead to increase in procurement regulatory compliance level by 0.699 .

The findings implied that the importance of implementing quality management is not well known to the top management in the procurement department. There exists a hindrance from the top management for the staffs to engage and enhance adoption and application of total quality management in procurement. Top management have not been motivating the staff individually for exemplar performance through rewards. Further, it was found that there is a poor working environment between the procurement staffs and the top management. Employees are denied freedom to discharge their duties as assigned to them by the top management. However, resources needed by staff to do their work are readily availed by the management.

\section{Conclusion}

Top management support is a good predictor of procurement regulatory compliance level. Managers can provide facilities and mobilize organizational resource to achieve high objectives. The adoption of total quality management is significantly influential to the procurement activities. Motivation and rewards to staff can be used as a strategy to combat the personal interest that arise in preference to fulfill their duties and assignments. Management acts as the framework to the functionality of the procurement department and activities thereof.

\section{Recommendations}

The existing hindrances from the top management for the staffs to engage and enhance adoption and application of total quality management in procurement should be eradicated. Top management instead should work on motivating the staff individually for exemplar performance. The management further should create an enabling working environment between the procurement staffs and the top management. There should be freedom of staff to discharge their duties as assigned to them by the top management. 
International Journal of Supply Chain and Logistics

ISSN 2520-3983 (Online)

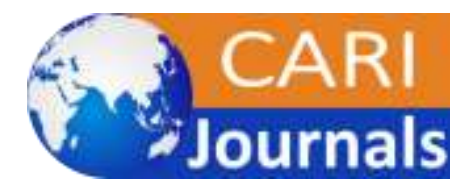

Vol.4, Issue 1, No.1, pp 1 - 12, 2020

www.carijournals.org

\section{REFERENCES}

Agaba, E. \& Shipman, N. (2017). Competing through Supply Chain Management and Creating Market winning Strategies through Supply Chain Partnerships. New York, International Thomsons Publishing.

Akech, J. M. M. (2015). Development partners and governance of public procurement in Kenya. Enhancing democracy in the administration of Aid. International Law and Politics, 37(4), 829-868.

Arrowsmith, S. (2015). The problem of discussions with tenders under the EC procurement directives, the current law and the case of reform. Public Procurement Law Review, 7(3), 65-82.

Davis, J. \& Canes, M. (2017). A Measure of Ethical Climate in Organizations ( $2^{\text {nd }}$ Ed).Hill, New York.

De Boer, B. (2017). Research methods. (4 ${ }^{\text {th }}$ Ed). New York, New American Library.

Donahue J. (2018). The Privatization Decision. New York. Basic Books

Etse, D. \& Asenso, B.M. (2014). Challenges of public procurement audit, A perspective of Ashanti regional office of Ghana audit services. International Journal of Economics, Commerce and Management, 2 (3).

Gelderman, J. C., Ghijsen, W. P. \& Brugman, J. M. (2017). Public procurement and EU tendering directives- explaining non-compliance. International Journal of Public Sector Management, 19(7), 702-714.

Getuno, P.M., Awino, Z.B., Ngugi, P.K. \& Ondiek, F. (2015). Public procurement legal framework implementation and performance of state corporations in Kenya. International Journal of Purchasing and Materials Management,2, 12-27.

Hui, W.S., Othman, R.O., Normah, O., Rahman, R.A. \& Haron, N.H. (2017). Procurement Issues in Malaysia. International journal of Public Sector Management, 24(6), 567-593.

Kipchilat, G.T (2006).An Evaluation of the Impact of the Public Procurement Regulations on Procurement in Kenyan Public Universities. Unpublished MBA Project. Egerton University, Nakuru, Kenya.

Mapesa, H.J. (2017). Cost of poor quality. International Journal of Strategic Cost Management, 2(4), 24-30. Masola Publishers.

Migosi, J., Ombuki, C. \& Evusa, Z. (2015). Consequences of procurement non-compliance behavior in public sectors in Kenya. Journal of Supply Chain Management, 39(1)14-25.

Nderui, N. \& Were, S. (2016). Factors affecting effective logistics management in manufacturing industry in Kenya. Strategic Journal of Business and Change Management, 4, 34-38.

Njeru, S.E., Ngugi, P.K., Arasa, R.M. \& Kahiri, J.M.K. (2015). Factors affecting effective implementation of procurement practices in tertiary public training institutions in Kenya. Strategic Journal of Business and Change Management, 3, 30-36. 
International Journal of Supply Chain and Logistics

ISSN 2520-3983 (Online)

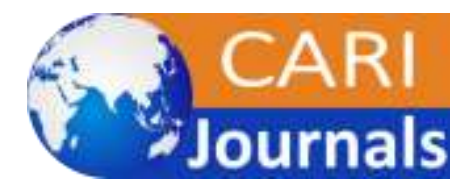

Vol.4, Issue 1, No.1, pp 1 - 12, 2020

www.carijournals.org

Obanda, W. P. (2016). Fighting corruption in tactical procurement. Unpublished PHD Dissertation, University of Twente.

Odhiambo, W. \& Kamau, P. (2015). Supply chain management as a new opportunity in Quality of procured goods in Non-governmental organizations. Strategic Journal of Business and Change Management, 2, 28-36.

Perry, M. (2017). The antecedents of buying firms efforts to improve suppliers. Journal of Operations Management, 17(2), 205-24.

Rossi, C. L. (2016). Compliance as an over-looked business strategy. International Journal of Social Economics, 37(10), 816-831.

Tom, D.N. (2017). Purchasing and Materials Management with Text and Cases. (5 ${ }^{\text {th }}$ Ed). McGraw-Hill, New York.

Xingxing, Z. \& Kaynak.H. (2017). An agency theory perspective on supply chain quality. International Journal of Purchasing and Materials Management, 3(4), 13-19. 